\title{
All the Apocalypse a stage: The ritual function of apocalyptic literature
}

\begin{tabular}{|c|c|}
\hline $\begin{array}{l}\text { Author: } \\
\text { Hanre Janse v }\end{array}$ & an Rensburg ${ }^{1}$ \\
\hline $\begin{array}{l}\text { Affiliation: } \\
{ }^{1} \text { Department } \\
\text { Testament an } \\
\text { Literature, Fac } \\
\text { Theology and } \\
\text { University of } \\
\text { Pretoria, Sout }\end{array}$ & $\begin{array}{l}\text { New } \\
\text { Related } \\
\text { ulty of } \\
\text { Religion, } \\
\text { retoria, } \\
\text { Africa }\end{array}$ \\
\hline $\begin{array}{l}\text { Research Proj } \\
\text { Project Leade } \\
\text { Rensburg }\end{array}$ & $\begin{array}{l}\text { ect Registration: } \\
\text { r: H. Janse van }\end{array}$ \\
\hline $\begin{array}{l}\text { Description: } \\
\text { This research } \\
\text { research proje } \\
\text { Functional An } \\
\text { by Dr Hanré J } \\
\text { Rensburg, De } \\
\text { New Testame } \\
\text { Literature, Fac } \\
\text { Theology and } \\
\text { University of }\end{array}$ & $\begin{array}{l}\text { s part of the } \\
\text { ct 'Ritual and } \\
\text { alysis', directed } \\
\text { inse van } \\
\text { artment of } \\
\text { t and Related } \\
\text { ulty of } \\
\text { Religion, } \\
\text { retoria. }\end{array}$ \\
\hline $\begin{array}{l}\text { Correspondin } \\
\text { Hanre Janse v } \\
\text { hanre.janseva } \\
\text { up.ac.za }\end{array}$ & $\begin{array}{l}\text { g author: } \\
\text { an Rensburg, } \\
\text { nrensburg@ }\end{array}$ \\
\hline $\begin{array}{l}\text { Dates: } \\
\text { Received: } 23 \\
\text { Accepted: } 15 \\
\text { Published: } 29\end{array}$ & $\begin{array}{l}\text { ept. } 2019 \\
\text { Oct. } 2019 \\
\text { Nov. } 2019\end{array}$ \\
\hline $\begin{array}{l}\text { How to cite th } \\
\text { Janse van Ren } \\
\text { 'All the Apoca } \\
\text { The ritual fun } \\
\text { apocalyptic lit } \\
\text { HTS Teologies } \\
\text { Theological St } \\
\text { a5822. https:/ } \\
\text { 10.4102/hts.v }\end{array}$ & $\begin{array}{l}\text { is article: } \\
\text { sburg, H., 2019, } \\
\text { ypse a stage: } \\
\text { tion of } \\
\text { erature', } \\
\text { e Studies/ } \\
\text { udies 75(4), } \\
\text { /doi.org/ } \\
75 \text { i4.5822 }\end{array}$ \\
\hline $\begin{array}{l}\text { Copyright: } \\
\text { (C) 2019. The } \\
\text { Licensee: AOS } \\
\text { is licensed un } \\
\text { Creative Com } \\
\text { Attribution Lic }\end{array}$ & $\begin{array}{l}\text { uthors. } \\
\text { IS. This work } \\
\text { ler the } \\
\text { nons } \\
\text { ense. }\end{array}$ \\
\hline Read online: & \\
\hline 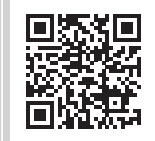 & $\begin{array}{l}\text { Scan this QR } \\
\text { code with your } \\
\text { smart phone or } \\
\text { mobile device } \\
\text { to read online. }\end{array}$ \\
\hline
\end{tabular}

It has been made clear for quite some time that if the Bible has become a classic of Western culture because of its normativity, then the responsibility of the biblical scholar cannot be restricted to giving readers clear access to the original intentions of the biblical writers. It must also include the question: 'What does a reading of the biblical text do to someone who submits to its world of vision?' This is a question that has been especially significant in the study of apocalyptic literature, as all apocalypses are hortatory. The implication is that, even in the historical context in which the text was first produced, there is room to consider the earliest stages of audience interaction with the text. Interestingly, most studies making use of this model do not address what the implications of this kind of 'reading as performance' might be for today's reader. This research argued that in the understanding of the biblical text as an oral performance, there is a need to leave room for all that happens to a text after it leaves the author's hands. The method proposed urged 'performers' of texts to pay attention to how they bring themselves to interpretation. More specifically, this method aimed to make use of ritual and liturgy as the rhetorical or performative context within which biblical texts functioned and still function. This research thus proposed a liturgical-functional reading reading of biblical texts which integrates affective reading and the deliberate move from cognitive to affective processes.

Keywords: the Apocalypse of John; the Book of Revelation; apocalyptic literature; affective reading; liturgical or functional reading; anamnesis; hope.

\section{A personal confession - Choosing the Apocalypse of John}

For as long as I can remember, I have been fascinated by the end of the world and, more specifically, the Book of Revelation's role in it. It seems that the more pessimistic society becomes and the more negative the future predicted for the world is, the more copious the amounts of performance art or entertainment produced on the subject becomes. Now, apart from the specific 'zombie apocalypse' sub-genre, most end-of-the-world horror still contains supernatural elements (e.g. 100 Prophecies 2016; Arora 2015; Burns 2015; End Times Prophecy 2016; Jehovah's Witnesses 2012, 2015; McNamara 2016; Rao 2014; Rhodes 2008, Signs of the End Times 2016; Tetlow 2016; The Mark of the Beast 2016a, 2016b). And so many of those supernatural elements - elements that have now become an integral part of pop culture, whether directly or indirectly (Wikipedia 2019a, 2019b, 2019c) - still stem from the Apocalypse of John. ${ }^{1}$ The world keeps redressing and repeating the events depicted in the Book of Revelation, and millions of people worldwide cannot get enough of these performances. They cannot stop because it enlivens their deepest fears in all their gory glory, allowing them to experience all of them (to revel in them) from a safe distance, and, once purged, to continue on with their daily existence.

It is this irony that led me back to the Book of Revelation for this study. In our hands, we have one of the most powerful stories that addresses the human condition - our existential angst; our fantasies regarding reward and punishment; our fascination with, and loathing of, violence and destruction; our questions regarding the place of God or good and the Devil or evil in all of these things; and so on. A story that has been used continuously in the entertainment industry throughout its history because of its popularity and the monetary success it guarantees. Yet, we as the church do not recognise the Apocalypse's power as performative text. This is reflected in our study of the Book of Revelation, for when studying past and present work on the 1.This does not mean to infer that the Bible as such has become a classic of Western culture, merely that specific images and ideas from the Book of Revelation have become part of Western culture. 
Apocalypse, it seems that we as exegetes have become so engrossed with studying the different aspects of Revelation - whether it be textual, symbolic, historical and so on - that we have lost sight of the stage or bigger picture it aims to present. And, in most cases, even when we as biblical scholars and exegetes do acknowledge the key performative aspect of the Apocalypse, it is not necessarily explored in any further detail. Despite the ever-increasing host of studies devoted to cognitive research in literary studies, to my knowledge, little attention has been paid to the specific role played by the affective processes foregrounded by neuroscientific researchers such as Antonio Damasio and Joseph LeDoux (1998).

\section{The aim of this research}

It is because that I decided to attempt to take back the stage that the Book of Revelation presents us with by making use of a liturgical-functional method of analysis. ${ }^{2}$ Such a liturgicalfunctional reading of the text cannot succeed if it is not linked up with 'affective reading' - a sub-division of Rhetorical Criticism that aims to substantiate that the emotional and embodied impact of the reading of texts should not be ignored or underestimated:

\begin{abstract}
'Affective reading' is a bidirectional term that refers to both reception and composition. In terms of reception, affective reading points to the impinging sensation that the process or activity of reading enacts in synthesis with a reading body. This receptive affection is produced through the composition of language programmed to execute discrete or 'coded' affects in the embodied materiality of the reader, to effect an 'affective reading' through the bodily matters of the reader, or to compose the body as a reading machine. This understanding of affect may be traced through the works of Spinoza, Gilles Deleuze, and Brian Massumi. (Bianco 2007:4-5)
\end{abstract}

It is the power of a body to possess capacities to 'impinge' upon bodies and to be impinged upon itself (De Spinoza 1955:97). Literary or exegetical studies and theory have recently experienced a challenge from critics interested in applying the insights of cognitive science research for the purposes of rethinking the process of reading. As I understand it, this research has successfully mounted a strong objection to the dominance of formalist and semiotic models that abstract from the site of reading as an embodied exercise (e.g. works such as Turner's Reading minds (1991) and The Literary mind (1996), and Lakoff and Johnson's recent Philosophy in the Flesh (1999). In various ways, these and related studies have highlighted the necessity for closer attention to the cognitive work involved in reading, suggesting that such attention has the valuable effect of dissolving many of the purported aporias endemic to language on the formalist paradigm and, indeed, of rejuvenating exegetical studies through a much-needed encounter with recent work in science.

2This method is not meant to subvert or replace previous research performed on reading Revelation in an eschatological (specifically apocalyptic) light. The proposed method is mean to function method is meant to function as a supplementary method when reading eschatological biblical texts. Although this method is not necessarily new, it is method that has not really been made use of in the reading of eschatological biblical texts, specifically the Book of Revelation.

\section{Defining the liturgical-functional method}

With this method of analysis, I begin to explore the function of affective processes in reading in a way that does not follow the cognitivist tendency (both in the new field of 'literary cognitivism' and in psychology more generally) to assimilate affect into cognition. The crucial operation of such an exploration, at least as I now understand it, is the frustration or short-circuiting of the normal process through which the cognition of metaphoric language bubbles up out of more basic embodied processes (e.g. those involved in the emotional centres of the brain, the limbic system and the hypothalamus). This short-circuiting, I argue, suspends the reader's capacity to cognise metaphors on the basis of their embodied core (what Lakoff and Johnson have recently called 'primary metaphors'). This suspension, in turn, gives rise to an affective response that makes achieving the ideal reading effect possible - proper 'understanding', by way of the affective process. The affective process incites an affective response or bodily reaction in the reader that constrains a literally excessive (virtual) text by 'adapting' it to, or 'actualising' it in, terms of the embodied, affective processes of each of its concrete readers. Speeches and texts compete for the attention, emotions, aesthetic pleasure and, sometimes, approval of their addressees.

So, this liturgical-functional reading is an exploration of the function of affective processes in reading by identifying determining variables of cognitive and affective processes. One aspect of affective literacy involves the immediate somatic ways we touch, sense, perceive, vocalise or perform a text with our eyes, hands, mouths and bodies. Another aspect of affective literacy is the range of emotional, spiritual and somatic responses readers have to a text, such as crying, laughing, becoming angry or becoming aroused (Amsler 2001:83). 'Affective literacy or reading' seeks out the life principle, messy and complex, threading through reading activities and gestures towards bodily economies of reading and transacting texts. As a potentially unruly practice, affective literacy challenges the assumption that reading is a unilateral consumption and a text is a discrete object (Amsler 2001:84).

It is the experience of an utterance or text that is its meaning (Fish 1970:131). In this respect, affective literacy foregrounds the hinge of reading which opens and closes a gap between reader and text, between the skin of the page and the reading body, between understanding and response and between repetition and difference. Therefore, affective reading produces textuality and reading responses in the fluid space between material language, comprehension and imagination, and between writing and the reader's reading body (Amsler 2001:94). Affective reading, then, is marked as a trace on the skin, in and out of time and on or in the book (Amsler 2001:97).

With this proposed liturgical-functional reading, the focus thus shifts back onto the text as a performance, a drama to be 
participated in. The drama, the conflict and the emotional and embodied effect of the events played out on the people participating in the performance of the text become the focus of analysis. I aim to identify and start exploring a method of exegesis of the text which allows us to, once again, physically participate in the Book of Revelation. Practically speaking, this implies a focus on, or highlighting of, a selection of words and phrases in the Book of Revelation that are repeatedly vocalised. In this repetitive vocalisation, constructive sensory or embodied experience is accentuated. This implies that in the performance ('acting out') of Revelation's experiential or liturgical scenes, these words and phrases play an essential part in the narrative's emotive and evocative impact. This focus on liturgical-functional and affective reading, more specifically, the performance of it and our participation therein, enlivens the conflict between opposed ideas and opposite poles once again. We are viscerally engaged in the battle between hopelessness and hope, and the drama described in the Apocalypse of John becomes more than just an old text, taken off the shelf only sometimes, and then mostly to scare people with.

\section{Revelation and liturgy or ritual}

Revelation 1:3 states in the introductory macarism: 'Blessed is the one who reads aloud the words of the prophecy ...' Is the character of Revelation thus essentially dramatic? A literary form meant to be read aloud? Indeed, to be performed as a combination of liturgical and theatrical experiences? (Court 1994:16) Despite its heavy visual symbolism, the Apocalypse depends, for its initial effect, on an aural response (Knight 1999:143).

The fact that the Apocalypse is an instance of secondary orality, in which a reader 'sounds again' the words written on the page ( $\operatorname{Rv} 1: 3$ ), is widely accepted (Aune 1997:liv, 2012:174). The orality of the Apocalypse means we should expect the text to have relatively clear divisions that are clear to the ear and do not need minute textual details to disclose them (Knight 1999:143). It is often stated that at the very heart of Revelation are the hymnic and doxological passages that pervade the book (e.g. Rv 1:4-8, 12-19; 4:1-11; 5:9-14; 11:15-18; 15:2-4; and 19:1-8; Hagner 2012:747). Charles (1920) put it this way:

Though our author has for his theme the inevitable conflict and antagonism of good and evil, of God and the powers of darkness, yet his book is emphatically a Book of Songs. (p. xiv)

But, in understanding the Apocalypse as an oral performance, the meaning now cannot simply be in its words. To talk exclusively of the author's intention (even if collectively expressed of the author's community) would be regarded as unforgivably one-sided in terms of the modern approach to a literary text (Court 1994:17).

There is a need to leave room for all that happens to a text after it leaves the author's hands. Even in the historical context in which the text was first produced, there is room to consider the earliest stages of audience interaction with the text. Umberto Eco (1984:49) borrows from aesthetic theory (as defined in the seminal work of Adorno 1970) the phrase 'open work' to describe the way art yields varieties of interpretation. While at a physical level, a work of art is traditionally complete unto itself and closed, at the same time it constitutes:

[A]n open product on account of its susceptibility to countless different interpretations which do not impinge on its unadulterable specificity. Hence every work of art is both an interpretation and a performance of it, because in every reception the work takes on a fresh perspective. (Eco 1984:49)

So, the meaning of Revelation has to be in the experience it provided to the audience, for Revelation only makes sense if there are hearers or readers to supply a sensibility to John's sounds and visions of the end of the world (Maier 2002:11). An experience in which one hears the voice of John and, more significantly, the voice of Jesus (e.g. 'I John ...' in Rv 1:9; and 'I Jesus ...' in Rv 22:16).

Viewed this way, the purpose of the Apocalypse is not just to communicate information - it is a portrayal of experience, not a reflection on it (Barr 2010:648). This means that the text of the Apocalypse is no longer seen as just an object, a thing-initself; but rather as an event, as something that happens to, and with the participation of, the reader (Fish 1970:125). It is this event, this happening that can, I would argue, provide a new perspective on the impact and meaning of the text. Of course, the value of such a procedure is predicated on the idea of meaning as an 'event'; as something that is happening between the words and in the reader's mind. My interest is to identify the means of persuasion used in Revelation's literary argument (Lewin \& Perpignan 2012:757-762). Whatever is persuasive and illuminating about this analysis is the result of my substituting one question - 'What does this text mean?' with another (more operational) question - 'What does this text $d o$ ?' The goal of the method of interpretation proposed by this study is thus to discern, appreciate and understand not only the meaning of the text in itself, but also the work performed among the community of hearers by the text in the performance. It is the hypothesis of this study that in the Book of Revelation, we have an indispensable resource for helping Christians conceive of their place in the contemporary world, and meditate on the role the church is to play in a modern, secular society.

\section{The Apocalypse: An 'open book'}

John's Apocalypse is not a nostalgic trip down memory lane, it is a form of anamnesis or recollection (Maier 2002:19). For John, the death of Jesus is, of course, a past historical event; but its reality is present and its effects are to be felt now. Anamnesis invests the present with renewed significance, for the present now carries the past.

In apocalyptic thought, when the bastions of goodness seem to have crumbled beyond recognition or repair, God remains sovereign, and thus, 'a cosmic renewal occurs, or a golden 
age arrives, or the earth is transformed into a paradise' (Cook 1995:28). Neither the worst that bad people can do, nor the best that good people can do limits what can happen; only God has that power and potential (Jones \& Sumney 1999:31). This conviction that God can and will unveil power, goodness and justice as yet unseen must find some way from the heart and soul to the hands and feet. What we believe about God should influence, form and shape what we do and think. In fact, it has been said that 'it is existentially impossible to believe in God's coming triumph and to claim [God's] Holy Spirit without a lifestyle that conforms to that faith' (Beker 1982:110). In this sense, all apocalypses are hortatory discourses that encourage ethical living and that specify what that means. So, apocalyptic literature does not entirely abandon the world to evil. The people of God are expected to act justly and to work for a more just world, even though the forces against them are overwhelming (Jones \& Sumney 1999:22). This reflects the heart of apocalyptic thought (Käsemann 1969):

Belief that God shows no partiality calls for our impartiality.

Belief that the power of God finds its fullest expression in love calls for fewer acts of domination and many more acts of compassion.

Belief that God hears the cries of the oppressed and promises release calls for our acts of justice and liberation.

Belief that God sends the gospel because of our need and not because of our merit calls for nothing less than a reordering of human relationships. (pp. 108-111)

This brings us to the theological centre of apocalyptic thought - the life and ministry of Jesus the crucified, resurrected and enthroned Christ (Jones \& Sumney 1999:34). The Jesus of apocalyptic thought is crucified because crucifixion indicates that evil is as powerful as it is pervasive. Apocalyptic thought thus forces us to see, even on the heavenly Lamb of God, the marks of slaughter - this reminds us of the cost and nature of our salvation. 'Resurrection cannot be celebrated if no one is dead' (Craddock 1986:275). Christian faith does not allow us to escape suffering - it clings to God by a thread called hope in the midst of, and despite, suffering. That thread expands and becomes a lifeline because this crucified Jesus is also resurrected. God, who is not limited to what we have yet seen and experienced, has an answer for the very worst humanity can do (Buttrick 1988:65).

We dare to face oppression and rejection because the triumph of God revealed in Jesus shatters any defeat humans can muster. The enthroned Jesus completes the picture, for authority abides in the Lamb. The details of that glory may not be as clear to us as are those of the world around us, but that does not diminish our confidence that glory will come. If the crucifixion-resurrection of Jesus is to be the paradigm for the Christian's eschatological expectation, then, in some sense, we must suppose ourselves as people of hope to be located on Easter Sunday (Bauckham \& Hart 1999:71). This day is bounded on the one side by all the horror of history, symbolically concluded in the events of Good Friday and on the other by the open future of God, who raises the dead to life on the dawn of Easter Sunday.

\section{A liturgical-functional reading of the Book of Revelation}

One way of assisting, ritually or practically, with this constant positioning as faith community is by looking at the Apocalypse - specifically regarding the resurrection - from a liturgical-functional point of view. Turning to Revelation, specifically looking for rituals to strengthen believers' understanding of themselves as located 'on Easter Sunday', quite a few possibilities present themselves. Because of the nature of this presentation, these possibilities can only be touched upon briefly. Studying the possible impact of pivotal texts in Revelation - for example, chapters 1, 4-5, 7, 11, 14-15, 19 and 21-22 - makes it clear that although Christian communities may find themselves driven into a kind of ghetto by the world's persecution, this does not justify 'escapism' and other worldly retreat. The book has a universal perspective and a sense of worldwide mission and interaction with the world. For the Seer, Christian witness follows the path of Christ from suffering to glory. The book leaves the reader with the impression that, however, powerful the forces of evil appear to be, the reality is very different. The faithful may lose their lives, but the gracious Lamb of God will bless them eternally. Their deeds of faith in an evil world will follow them to the throne room of heaven where, at last, they will find rest. Believing this promise changes the world from a place tied to our limits to a place touched by the limitless potential of God. There is no more triumphant book than this in the New Testament - here the modern church can, as could Revelation's first audience, find fresh courage.

Then, there is also the variety of expressions to be found in the Apocalypse, which open up a world of possibilities where performative action is concerned: There is the golden thread of the constant prayers and songs of celebration of the identity, the majesty and the power of God (e.g. Rv 4:8 and 11; $5: 9-10,12-13 ; 7: 10$ and $12 ; 11: 15-18 ; 14: 1-3 ; 15: 3-4 ; 16: 5,15$; and 19:1-7); for those times when the chaos of the world seems overwhelming, there are supplications with which to voice the anguish, frustration and impatience experienced (e.g. Rv 6:10-11; 16:15; and 22:17 and 20); there are examples of the blessings that await those who suffer in the name of Christ, which could serve as a balm when experiencing the cruelty of the world (e.g. Rv 12:10-12; 14:7 and 13); and then there are also those statements that deal with the darkness of the world, with sinners questioning themselves and with the eventual fall and total humiliation or destruction of all who stand against God (e.g. Rv 6:16-17; 14: 8; and 18:2-7, 9-10, 16-24). In terms of the way in which these prayers, supplications and songs can become a part of our ritual and symbolic actions, the possibilities are legion. Whatever form they may take, the goal will always be that, by playing and performing these new actualities, they are subconsciously and consciously brought into existence.

Revelation's ritual experience is strengthened even further by the ritual actions or gestures and symbols which the book is filled with, gestures that can be used when partaking in 
performative actions to enrich and deepen the experience of the participants. A few examples: incense as a symbol of both prayer and God's glory, power and blessing ( $\mathrm{Rv} 8: 3-4$; and $5: 8-10)$; the sealing or anointing and marking of those who believe, as promise and protection ( $\operatorname{Rv} 7: 2-3$; and 22:4); the sacrifice or blood of the Lamb and the martyrs (Rv 7:14; and 12:11); the washing of robes and the importance of new and white or pure robes ( $\operatorname{Rv} 7: 13-14$; and 22:14); and the crowning or reward of the faithful ( $\operatorname{Rv} 2: 10 ; 3: 11 ; 4: 4 ; 20: 4 ; 21: 3-7$; and 22:1-5).

\section{Revelation's sensory pageantry}

The Apocalypse thus allows us, indeed requires us, to reexperience the work, both as story and as continuing experience (Barr 2001:112). The Apocalypse employs the language of liturgical hymnody in an active way to map out an alternative world view for Christians, so shaping a strategy of resistance (Ruiz 2001:84). In their heroic witness to the power of the sovereign that the Apocalypse's heavenly choirs identify as 'our God', such resistance promised Christians of the seven churches the sort of share in the slaughtered Lamb's paradoxical victory that would gain them admission to the chorus of those who sing praise around God's throne. It is no accident that the only humans who participate in the Apocalypse's heavenly worship are those who 'come out of great tribulations' (Rv 7:14), and who 'have overcome/defeated the Beast, his image, his number and his name' $(\operatorname{Rv} 15: 2-3)$. It is in this sense that the Apocalypse continues to inspire a vision of hope for many readers. The Book of Revelation focuses on exhortation, which stresses the importance of standing firm in faith and love, and enduring tribulation (Court 2000:10). This exhortation is reinforced by eschatological threats and promises.

The Christian Apocalypse consoles those who glimpse what hell can be and encourages those who would build a New Jerusalem (Court 1994:11). On this basis, the Revelation of John develops an impressive sacral architecture - by presenting a heavenly reality within the framework of an apocalyptic vision of history, it provides a new interpretation for earthly events and experiences. The author develops a theology in visionary pictures of the cultic reality in heaven and on earth, aiming to strengthen the threatened identity of his churches and to orient it by this new symbolic universe. Those experiencing the conflict are assured of the victorious outcome. Whatever the weight of evil opposition, there is no possibility of its ultimate success. The assurance that the consummation of history is not fortuitous, but is firmly in the hands of God, is of the highest relevance in an age threatened with self-destruction. The New Jerusalem vision, with which the book fittingly ends, is a positive hope for all who have embraced the Christian gospel. The end of the present age will not come until the way has been opened for a glorious future, which evil will be powerless to spoil. At the same time, this cultic thought-world grants participation in the event itself (Schnelle 2009:751). If the passages concerned are a vital key to the appreciation of the
Apocalypse as a whole, which seems undeniable (Guthrie 1987:88), we should not wrest them from their context without taking into account their essentially eschatological purpose. The liturgical passages are not an end in themselves, but lead up to the great crescendo in Revelation 21 and 22.

The Apocalypse affirms God's sovereignty and the ultimate fulfilment of God's purpose. In this way, it offers strong support to individuals in maintaining their faith. It is a book for the Christian, the church and the world. To those who share its faith, although they may not hold it in precisely the same form as its author, it gives assurance of the victory of God and the triumph of the Lamb. Here, we need to give full weight to the ideas and images contained in its visions. We do not need to take Revelation literally, but we should take it seriously, for it shows a relationship between pain, martyrdom and Christian belief. Moreover, it clearly depicts a continuity between past, present and future for the church and the individual believer, from which the disillusioned churches of today can learn (Court 2000:7).

\section{A wager on transcendence}

The Christian story - especially as described in the hymnic or ritual material of the Apocalypse - thus affords a route beyond the modern-day impasse, an exit from the labyrinth of postmodern despair, an environment in which an ecology of hope can flourish. It does so precisely by virtue of its own peculiar 'wager on transcendence', not only on a vertical transcendence but also on a horizontal transcendence - a transcendent God whose way of being transcends ours and our world in the present moment; a God who faithfully awaits us beyond the very end of history itself.

We have to wager on a God whose capacities are such as to fashion out of our tragic endings (both individually and as a race) a future which wholly transcends the potential latent within history. We must leave the stage where the tragedy is being played out, and appeal to a wider vision of reality than its limited scenery allows us (Bauckham \& Hart 1999:51). Forced to resort to an appeal beyond this world and its intrinsic capacities altogether to another world as the sole guarantor of ultimate meaning and purpose - the sole source of genuine hope. This 'wager' within the story which the author of the Apocalypse of John tells us about is more familiarly referred to as faith in the God of the resurrection. In faith, our imagination is engaged, stretched and enabled to accommodate a vision of a meaningful and bright future for the world, a future that could never be had by extrapolating the circumstances of the tragic drama of history itself. The 'comic' ending is unlooked for, unexpected and improbable in the extreme, while our imagination is constrained by the conditions of the immanent. Only by allowing our imagining to be blown wide open by a transcendence which blows the future itself wide open can we begin, however, partially and tentatively, to envisage a telos which may legitimately furnish us with an object of hope. 
A good place for our imagining to begin is with the performative use of the Apocalypse. In the Book of Revelation, the human story is provided with the wider vision it needs to be able to transcend this world.

Human race is provided with a saviour and a future that would never be possible were we left to our own devices. With the Apocalypse, the 'improbable resolution' to our problems is provided, rooted in the eternal God that exists beyond the story itself. The God who redeems and resurrects the immanent by his own sacrifice, enabling human race to not only imagine but also ritually experience a future which is genuinely other than this present. God, by 'making all things new' (Rv 21:5), provides the unexpected 'comic' ending. God opens up the immanent to the eternal, allowing us to step of this stage, and into a new world - the New Jerusalem. The point here is that the tragic dimensions of human life cannot, and will not, be resolved within the boundaries of either history or nature. The replacement of the existing order with one which is new and superior cannot be accomplished without a resolution of the present combat situation. If this story is to have a comic rather than a tragic ending, Christian faith recognises that it will only be through the contrivance of the God of the resurrection - the God who is able to bring life out of death and being out of non-being that all is resolved well and everything finally works together for good (Bauckham \& Hart 1999:68).

\section{Moving beyond convention: A re-enchantment of hope}

This book, with its strange poetic language, shows the powerful forces of evil ultimately brought to nothing.

There is never any doubt about the outcome - the Lamb is in control throughout. The supreme message of this book is one of genuine hope and encouragement. Genuine hope has the capacity to transfigure our perception and experience of the present, thus transforming our ways of being in the world. It is a vital part of a Christian perspective on this world to identify within it scattered acts of re-creative anticipation of God's promised future (Bauckham \& Hart 1999:70). The same Spirit who raised Jesus from death calls into being life, health, faith and hope where there is otherwise no capacity for these and no accounting for them. In such happenings, the power of the future-made-present is manifest, and the lustre of the new creation shines provocatively from behind the heavy clouds of history.

This Christian faith is evoked and sustained or nurtured by a rich stock of images and through an appeal to hope beyond the limits of the historical and the natural, in terms of which it becomes possible to imagine the unimaginable (Bauckham \& Hart 1999:69). If accepted subjectively as well as metaphorically, these expressions and rituals have the capacity to shape us by revealing new dimensions of imaginable being. A metamorphosis of imagery occurs, which extends beyond the dimensions of the reasoned intellect alone. In this performative ritual experience, the totality of a person can be transformed because previously hidden (subconscious) elements are now revealed. For, when continually confronted with the power and glory of the different elements of the symbolic descriptions of God, the faithful cannot be but ever-more secure, rooted in the power and majesty of the God they worship. Thus, when looking at the Apocalypse's eschatological imagery (as laid out above) from a liturgical-functional point of view, there are quite a few elements that do not only have significance in the hearing of them, but that can be used in physical ritual or performative ways to strengthen the liturgicalfunctional performance of, and participation in, the message of Revelation. In this way, the text as performance comes full circle.

\section{Reflections on concluding}

In this study, it is my hope that the following has been made clear: By using a ritual or liturgical functional reading of the Apocalypse of John, we finally give the 'hearing' or performance of the book the weighted consideration it deserves. As a result, the rhetorical power and gripping affective majesty of the Apocalypse is brought to the fore.

By making use of this idea of a functional reading of the text of the Apocalypse, it becomes possible to move beyond the often-perpetrated hermeneutic reduction of hope to two conventional poles - the early Christian movement's hope through reversal, and contemporary nihilism - by providing a third possibility that focuses on the power of the functional and performative aspects of Revelation. In this way, we move away from the idea of extreme poles into the hermeneutical spiral, which allows for the affecting of both conscious and subconscious change. This is especially important when we keep in mind that we as society are in dire need of something that transcends both ourselves and the intellectual circles we run in - if we are not to lose our essential humanity.

This investigation proposed that what is needed is something that transcends our intellect, our perception of reality and our working out of the end (if there is such a thing). In a liturgical-functional reading, we found the beginnings of endless possibilities that enable us to do just that. When focusing on ritual and function and its application for reading and understanding the text, we are forced to engage with our mind as a whole and with ourselves as embodied beings. The reading then is not only about criticism (or even understanding in the traditional sense) but also about allowing ourselves to be taken up into the ritual performance of the text in such a way that it affects us both consciously and subconsciously. This brings about a transcendence of ourselves that we need, opening us up to the previously unnoticed manifold possibilities that our reality and the future holds, without having rationally worked out anything.

Through the performance of, and our participation in, the ritual that is the Apocalypse of John, people today can find a 
unifying story - a story of past, present and future meaningfully intertwined; a story that provides clarity, purpose and substance; a story that connects; a story that excites us into living as our best selves. We are changed at a level deeper than our intellect can take us, and it has the potential to change everything.

All of the above could help us, in this meanwhile, to live and travel in hope; able to face squarely and in all their awfulness the horrific aspects of that history within whose temporal boundaries we actually still live. We would be able to do so, precisely and only because the terror of history no longer haunts us. Instead, through the captivity of our imagination, God's Spirit draws us forward into the reality of God's own future - a future of which the openness is no longer a threat, but a source of that joyful energy under the influence of which God calls us, for now, to live, labour and 'witness' in the world. Through participation in periods (rituals) where action and awareness merge, we experience the high and explicit sanctification of life's most primary concepts. The immediate and lasting effect of this is an embodied or lived experience of the preservation of the world's wholeness in the face of fragmenting and dissolving forces. Through participation, hope can be fused into our subconscious, from where it is able to affect our conscious daily living in a much more powerful way than merely thinking about it can ever achieve. For such a time and context as ours, this could be a game-changing method.

But only further study will illuminate just how much it can (and does) change this game called life, and our understanding of it and living in it.

\section{Acknowledgements}

This article is based on ideas first explored in my DTh thesis - ritual functions of the Book of Revelation: Hope in dark times - obtained in 2016 from the University of South Africa under the supervision of Prof. P.J.J. Botha in the Department of New Testament and Early Christian Studies (now a unit within the larger Department of Biblical and Ancient Studies). Prof. Pieter J.J. Botha started me down this specific research road with his supervision of my doctoral thesis.

\section{Competing interests}

The author declares that no competing interest exist.

\section{Author(s) contributions}

H.J.v.R. is the sole author of this study.

\section{Funding information}

This research received no specific grant from any funding agency in the public, commercial or not-for-profit sectors.

\section{Data availability statement}

Data sharing is not applicable to this article as no new data was created or analysed in this study.

\section{Disclaimer}

The views and opinions expressed in this article are those of the author and do not necessarily reflect the official policy or position of any affiliated agency of author.

\section{References}

100 Prophecies, 2016, Bible prophecies explained: End time prophecy from the Bible, viewed 29 June 2019, from http://www.100prophecies.org/page9.htm.

Adorno, T.W., 1970, Aesthetic theory, Theory and History of Literature 88, University of Minnesota Press, Minneapolis, MN.

Amsler, M., 2001, 'Affective literacy: Gestures of reading in the later middle ages', Essays in Medieval Studies 18(1), 83-110. https://doi.org/10.1353/ems.2001.0001

Arora, G., 2015, '10 Scientific predictions that the end of the world is near', Scoop Whoop, viewed 29 June 2019, from http://www.scoopwhoop.com/inothernews/ end-of-the-world/.

Aune, D.E., 1997, Word biblical commentary 52A: Revelation 1-5, Word Books, Dallas, TX.

Aune, D.E. (ed.), 2010, The Blackwell companion to the New Testament, Blackwell Publishing Ltd., Oxford.

Aune, D.E., 2012, 'The polyvalent imagery of Rev 3:20 in the light of Greco-Egyptian divination texts', in D.E. Aune \& F.E. Brenk (eds.), Greco-Roman culture and the New Testament: Studies commemorating the centennial of the Pontifical Biblical Institute, pp. 167-183, Brill, Leiden.

Aune, D.E. \& Brenk, F.E. (eds.), 2012, Greco-Roman culture and the New Testament: Studies commemorating the centennial of the Pontifical Biblical Institute, Brill, Leiden.

Barr, D.L., 2001, 'Waiting for the end that never comes: The narrative logic of John's story', in S. Moyise (ed.), Studies in the Book of Revelation, pp. 101-112, T \& T Clark, Edinburgh.

Barr, D.L., 2010, 'The Apocalypse of John', in D.E. Aune (ed.), The Blackwell companion to the New Testament, pp. 632-651, Blackwell Publishing Ltd., Oxford.

Bauckham, R. \& Hart, T., 1999, Hope against hope: Christian eschatology in contemporary context, Darton Longman \& Todd Ltd., London.

Beker, C.J., 1982, Paul's apocalyptic gospel: The coming triumph of God, Fortress Press, Philadelphia, PA.

Bianco, J.S., 2007, 'Affective I reading I affect', draft chapter for Cross Media Movements.

Burns, J., 2015, ' 5 signs of the end times unfolding before our eyes', Charisma News, viewed 29 June 2019, from http://www.charismanews.com/world/49561-5 signs-of-the-end-times-unfolding-before-our-eyes.

Buttrick, D.G., 1988, Preaching Jesus Christ: An exercise in homiletic theology, Fortress Resources for Preaching, Fortress Press, Philadelphia, PA.

Charles, R.H., 1920, Revelation. Volumes 1 and 2, International Critical Commentary, T \& T Clarke, Edinburgh.

Cook, S.L., 1995, Prophecy and apocalypticism: The postexilic social setting, Fortress Press, Minneapolis, MN.

Court, J.M., 1994, Revelation, New Testament Guides, Sheffield Academic Press, Sheffield.

Court, J.M., 2000, The Book of Revelation and the Johannine apocalyptic tradition, JSNT Supplement Series 190, Sheffield Academic Press, Sheffield.

Craddock, F.B., 1986, 'Preaching the Book of Revelation', Interpretation 40(1), 270-282. https://doi.org/10.1177/002096438604000305

Damasio, A.R., 1996, Descartes' error: Emotion, reason and the human brain, Harper Perennial, New York.

Damasio, A.R., 1999, The feeling of what happens: Body and emotion in the making of consciousness, Harcourt Brace, Orlando, FL.

De Spinoza, B., 1955, The ethics, transl. R.H.M. Elwes, Dover, New York.

Eco, U., 1984, The role of the reader: Explorations in the semitics of texts, Indiana University Press, Bloomington, IN.

End Times Prophecy, 2016, Signs of the end times, viewed 29 June 2019, from http:// www.end-times-prophecy.org/signs-end-times.html.

Fish, S., 1970, 'Literature in the reader: Affective stylistics', New Literary History 2(1), 123-162. https://doi.org/10.2307/468593

Guthrie, D., 1987, The relevance of John's Apocalypse, Paternoster Press, Grand Rapids, MI.

Hagner, D.A., 2012, The New Testament: A historical and theological introduction, Baker Academic, Grand Rapids, MI. 
Jehovah's Witnesses, 2012, The Bible: A book of accurate prophecy. Part 6: 'The last days', viewed 29 June 2019, from https://www.jw.org/en/publications/ magazines/g201210/the-last-days/.

Jehovah's Witnesses, 2015, The Bible's viewpoint: The end of the world, viewed 29 June 2019, from https://www.jw.org/en/publications/magazines/g201511/ when-will-world-end-bible-prophecy/.

Jones, L.P. \& Sumney, J.L., 1999, Preaching apocalyptic texts, Chalice Press, St. Louis, MO

Käsemann, E., 1969, New Testament questions of today, Fortress Press, Philadelphia, PA.

Knight, J., 1999, Revelation, Readings: A New Biblical Commentary, Sheffield Academic Press, Sheffield.

Lakoff, G. \& Johnson, M., 1999, Philosophy in the flesh: The embodied mind and its challenge to Western thought, Basic Books, New York.

LeDoux, J., 1998, The emotional brain: The mysterious underpinnings of emotional life, Simon \& Schuster, New York.

Lewin, B.A. \& Perpignan, H., 2012, 'Recruiting the reader in literary criticism', Text \& Talk 32(6), 751-772. https://doi.org/10.1515/text-2012-0035

Maier, H.O., 2002, Apocalypse recalled: The Book of Revelation after Christendom, Fortress Press, Minneapolis, MN.

McNamara, M., 2016, 'Cinemax drama "Outcast" shifts apocalypse from zombies to demons', Los Angeles Times, viewed 29 June 2019, from http://www.latimes. com/entertainment/tv/la-et-st-outcast-review-20160601-snap-story.html.

Moyise, S. (ed.), 2001, Studies in the Book of Revelation, T \& T Clark, Edinburgh.

Rao, N., 2014, 'Doomsday warning: World will end in the next seven years, warns terrifying prophecy', Express, viewed 29 June 2019, from http://www.express.co.uk/news/ weird/539587/End-of-World-Warning-natural-disasters-seven-years-prophecy.
Rhodes, M., 2008, 'Seven prophecies that must be fulfilled before Jesus Christ's return', United Church of God, viewed 29 June 2019, from http://www.ucg.org/ the-good-news/seven-prophecies-that-must-be-fulfilled-before-jesus-christsreturn.

Ruiz, J.-P., 2001, 'Praise and politics in Revelation 9:1-10', in S. Moyise (ed.), Studies in the Book of Revelation, pp. 69-84, T \& T Clark, Edinburgh.

Schnelle, U., 2009, Theology of the New Testament, Baker Academic, Grand Rapids, MI.

Signs of the End Times, 2016, Bible signs of the end times, viewed 29 June 2019, from http://www.signs-of-end-times.com/.

Tetlow, J., 2016, 101 End times Bible prophecy, viewed 29 June 2019, from http:// www.raptureforums.com/BibleProphecy/101lastdays.cfm.

The Mark of the Beast, 2016a, 2016 The time of the end, viewed 29 June 2019, from $\mathrm{http}: / /$ www.markbeast.com/70jubilees/summary-2015.htm.

The Mark of the Beast, 2016b, Does Bible prophecy foretell the end of the world? viewed 29 June 2019, from http://www.markbeast.com/endworld/prophecyend-world.htm.

Turner, M., 1991, Reading minds: The study of English in the age of cognitive science, Princeton University Press, Princeton, NJ.

Turner, M., 1996, The literary mind, Oxford University Press, New York.

Wikipedia, 2019a, List of apocalyptic films, viewed 29 June 2019, from https:// en.wikipedia.org/wiki/List_of_apocalyptic_films.

Wikipedia, 2019b, List of Christian films, viewed 29 June 2019, from https:// en.wikipedia.org/wiki/List_of_Christian_films.

Wikipedia, 2019c, List of religious films, viewed 29 June 2019, from https://en. wikipedia.org/wiki/List_of_religious_films. 